\title{
KAJIAN POTENSI ANTIOKSIDAN ALAMI BERBAGAI LIMBAH TANAMAN
}

\section{(THE STUDY OF POTENTIAL NATURAL ANTIOXIDANTS FROM PLANT WASTE)}

\author{
Rukiah Lubis $^{1}$, Nur Hidayah ${ }^{2}$, dan Nopriyeni ${ }^{1}$ \\ ${ }^{1}$ FKIP Universitas Muhammadiyah Bengkulu Indonesia \\ Jl. Bali PO. BOX 119 Kota Bengkulu \\ ${ }^{2}$ Fakultas Pertanian Universitas Tidar Indonesia \\ Magelang, Kec. Magelang Utara, Kota Magelang, Jawa Tengah \\ email: rukiah2507@umb.ac.id
}

\begin{abstract}
Abstrak
Tujuan dari penelitian ini adalah untuk menganalisis kandungan antioksidan (antosianin, vitamin A, C, dan E) dari limbah kulit buah senduduk (Melastoma malabathricum L.), jantung pisang, jengkol. Penelitian dilaksanakan selama enam bulan. Analisa antosianin dan vitamin A, C, dan E dilakukan di Balai Besar Industri Agro, Bogor. Bahan yang digunakan pada penelitian ini terdiri dari kulit buah senduduk, jantung pisang, dan jengkol. Analisis kandungan vitamin A dilakukan pada sampel mengunakan alat High Performance Liquid Cromatography (HPLC). Penentuan kadar antosianin dihitung menggunakan metode perbedaan $\mathrm{pH}$. Data yang diperoleh dianalisis secara deskriptif. Hasil penelitian menunjukkan bahwa aktivitas antioksidan alami yang paling tinggi menurut analisis kandungan vitamin A, C, E dan antosianin dari ketiga limbah tanaman (buah senduduk, jantung pisang, kulit jengkol), terdapat pada kulit buah senduduk dan kulit jantung pisang yaitu kandungan vitamin C (111.33 mg/kg dan $263.33 \mathrm{mg} / \mathrm{kg})$ dan kandungan antosianin (684.008 mg/100g dan $174.289 \mathrm{mg} / 100 \mathrm{~g})$. Dapat disimpulkan bahwa buah senduduk dan jantung pisang bisa dijadikan sebagai antioksidan alami yang baik berdasarkan hasil analisis kandungan vitamin A, C, E, dan kandungan antosianin.
\end{abstract}

Kata kunci: antioksidan alami, limbah tanaman, antosianin

\begin{abstract}
This study was aimed at analyzing the content of antioxidants (anthocyanins, vitamins A, C, and E) from the rind of sanduduk's fruit (Melastoma malabathricum L.), Blossom of the banana plant (Musa acuminata Colla), jengkol (Archidendron pauciflorum) fruit. The research was conducted for six months. Analysis of anthocyanins and vitamins A, C, and E was performed at Balai Besar Industri Agro, Bogor. The materials used in this research consisted of sanduduk rind, banana blossom, and jengkol fruit. Vitamin A content analysis was performed on the samples using High Performance Liquid Chromatography (HPLC). The determination of anthocyanin levels was calculated using the $\mathrm{pH}$ difference method. The data obtained were analyzed descriptively. The results showed that the highest natural antioxidant activity according to the analysis of vitamin A, C, E and anthocyanin content from the three wastes, found in sanduduk rind and banana blossom which contain vitamin $\mathrm{C}(111.33 \mathrm{mg} / \mathrm{kg}$ and $263.33 \mathrm{mg} / \mathrm{kg})$ and anthocyanin $(684.008 \mathrm{mg} / 100 \mathrm{~g}$ and $174.289 \mathrm{mg} / 100 \mathrm{~g})$. It can be concluded that sanduduk fruit and banana blossom can be used as a good natural antioxidant based on the results of analysis of vitamin A, C, E, and anthocyanin content.
\end{abstract}

Keywords: natural antioxidant, plant waste, anthocyanins

\section{PENDAHULUAN}

Tingginya mobilitas kendaraan bermotor dan kegiatan perindustrian menyebabkan perubahan keseimbangan ekologi, salah satunya pencemaran udara. Pencemaran udara berdampak negatif bagi kesehatan 
manusia. Berbagai penyakit seperti paruparu, radang saluran pernapasan, dan kanker merupakan efek negatif polusi udara yang masih harus dicari solusinya. Di Indonesia yang berpenduduk sekitar 225 juta orang setiap tahun terdapat 0,1 persen atau 225.000 penderita baru penyakit kanker. Setiap tahun ada penambahan sekitar 6-10 juta penderita kanker di dunia. Badan Kesehatan Dunia (World Health Organization/ WHO) memprediksi bahwa pada tahun 2030 jumlah penderita kanker di Indonesia akan meningkat tujuh kali lipat. Kanker paru, hati, usus, kolorektal, payudara dan serviks merupakan beberapa jenis kanker yang paling banyak ditemukan di Indonesia.Lima besar penyakit kanker yang sering terjadi di Indonesia adalah kanker leher rahim, payudara, kelenjar getah bening, nasofaring, dan kulit (Okezone, 2018)

Polusi udara menghasilkan zat oksidan atau yang dikenal dengan nama radikal bebas. Radikal bebas membahayakan kesehatan karena sifatnya yang merusak jaringan tubuh. Zat ini selain berasal dari luar juga dihasilkan di dalam tubuh melalui proses metabolisme. Radikal bebas akan mengambil elektron dari sel tubuh manusia yang dapat menyebabkan perubahan struktur DNA. Radikal bebas dapat bereaksi dengan membran phospolipida sehingga mengakibatkan mutasi, inisiasi dan perubahan asam nukleat, memicu terjadinya kanker serta kerusakan sel. Antioksidan merupakan senyawa yang dapat menghambat reaksi oksidasi atau suatu zat yang dapat menetralkan atau menangkap radikal bebas (Kumaran \& Karunakaran, 2006). Antioksidan eksogen (dari luar tubuh) yang umum digunakan adalah vitamin $\mathrm{C}$, vitamin $\mathrm{E}, \beta$-karoten, dan komponen-komponen yang terkandung dalam tanaman seperti polifenol dan bioflavonoid.

Beberapa limbah tanaman yang diduga berpotensi menjadi sumber antioksidan alami yaitu kulit buah senduduk, jantung pisang, dan jengkol. Limbah ini memiliki ciri warna kulit yang keungunan mirip seperti kulit manggis dengan kandungan antosianin yang tinggi.Kulit-kulit tanaman ini hanya dibuang tanpa dimanfaatkan secara optimal. Sementara buah atau bijinya dimanfaatkan sebagai makanan ataupun obat tradisional. Buah dan biji jengkol diketahui mengandung senyawa bioaktif tanin, saponin, flavonoid, alkaloid, glikosida, dan steroid. Diduga kulitnya memiliki kemiripan dengan buah atau bijinya yang mengandung senyawa bioaktif ataupun senyawa lain yang berpotensi digunakan sebagai antioksidan alami. Sampai saat ini belum banyak informasi mengenai persentase kandungan antioksidan dari kulit tanaman buah senduduk, jantung pisang dan jengkol. 
Penelitian ini bermaksud untuk mengeksplorasi potensi kandungan antioksidan limbah tanaman (kulit buah senduduk, jantung pisang, jengkol) yang jumlahnya melimpah di Provinsi Bengkulu namun belum dimanfaatkan secara optimal. Target utama dari penelitian ini yaitu memanfaatkan limbah kulit tanaman tersebut yang selama ini hanya dibuang menjadi alternatif sumber antioksidan alami.

\section{METODE}

Penelitian dilaksanakan selama enam bulan. Analisa antosianin dan vitamin A, C, dan E dilakukan di Balai Besar Industri Agro, Bogor.Bahan yang digunakan terdiri dari kulit buah senduduk, jantung pisang, dan jengkol. Seperangkat alat dan bahan untuk antosianin, vitamin A, C, dan E. Data yang diperoleh dianalisis secara deskriptif.

Tahap analisis parameter antioksidan sebagai berikut. Pertama, persiapan sampel. Limbah tanaman yang terdiri dari kulit buah senduduk, jantung pisang, dan jengkol dikering anginkan (kering layu) selama 5-6 jam dibawah terik matahari. Setelah itu dikeringkan dengan menggunakan matahari sampai didapatkan bobot sampel yang stabil. Sampel yang sudah kering digiling dengan menggunakan mesin penggiling untuk mendapatkan sampel bahan dalam bentuk tepung.
Kedua, vitamin A, C, E (IU). Analisis kandungan vitamin A dilakukan pada sampel mengunakan alat High Performance Liquid Cromatography (HPLC). Kuning telur yang dianalisis merupakan hasil komposit dari setiap ulangan dalam perlakuan.

Ketiga, antosianin. Identifikasi antosianin dengan cara Identifikasi ekstrak meliputi identifikasi warna dengan $\mathrm{HCl}$ dan $\mathrm{NaOH}$, identifikasi dengan Spektrofotometer Uv-Vis, dan identifikasi Gugus Fungsi dengan FTIR. Penentuan kadar antosianin dihitung menggunakan metode perbedaan $\mathrm{pH}$ yaitu pada $\mathrm{pH} 1$ dan $\mathrm{pH}$ 4,5. Dua larutan sampel disiapkan dari masing masing filtrat, pada sampel pertama digunakan larutan $\mathrm{pH} \quad 1,0$ dan untuk sampel kedua digunakan larutan $\mathrm{pH}$ 4,5. Diukur dengan menggunakan Spektrofotometer Uv-Vis. Absorbansi dari setiap larutan pada panjang gelombang maksimum dan panjang gelombang $700 \mathrm{~nm}$. Kadar total antosianin dapat dihitung dengan menggunakan rumus pada Persamaan (1) dan (2).

$$
\begin{gathered}
\mathrm{A}=(\mathrm{A} \lambda \max -\mathrm{A} 700) \mathrm{pH} 1.0-(\mathrm{A} \lambda \max -\mathrm{A} 700) \mathrm{pH} 4.5(1) \\
\text { Total Anthocyanin }(\mathrm{mg} / \mathrm{L})=\mathrm{A} \times \mathrm{BM} \times \mathrm{DF} \times 1000 / \mathrm{exl}(2)
\end{gathered}
$$

Keterangan:

$$
\begin{aligned}
B M= & \text { berat molekul Sianidin-3- } \\
& \text { rutinosida }(445,2 \mathrm{~g} / \mathrm{mol}) \\
D F= & \text { faktor pengenceran } \\
E= & \text { absorptivitas molar sianidin-3- } \\
& \text { rutinosida }(28.800 \mathrm{~L} /(\text { mol.cm })) \\
L= & \text { tebal kuvet }(1 \mathrm{~cm})
\end{aligned}
$$




\section{HASIL DAN PEMBAHASAN}

Untuk mengetahui senyawa antioksidan yang terkandung didalam beberapa limbah tanaman, maka salah satu analisis yang dapat dilakukan dengan melihat kandungan vitamin A, C, dan vitamin E. Vitamin A, vitamin $C$ dan vitamin $E$ merupakan senyawa antioksidan alami yang sering digunakan sebagai senyawa pembanding dalam pengujian aktivitas antioksidan (Lung \& Destiani, 2017). Hal ini dikatakan demikian karena senyawa antioksidan alami relative aman dan tidak menimbulkan toksisitas. Tabel 1 menunjukkan rataan kandungan vitamin yang terdapat pada sampel yang diteliti.

Pertama, vitamin A. Dari analisis yang dilakukan, pada rata-rata kandungan vitamin A dapat dilihat bahwa dari semua sampel memiliki kandungan vitamin A yang rendah yaitu berada pada kisaran $<0,50$ IU/100g. Salah satu penyebab rendahnya kandungan vitamin A dipengaruhi oleh pengeringan yang dilakukan di bawah sinar matahari. Kandungan vitamin A sangat sensitif terhadap cahaya, udara, dan suhu yang tinggi. Kandungan vitamin A pada ubi jalar mentah lebih tinggi $(1165 \mathrm{mg} / 100 \mathrm{~g})$ dibandingkan dengan ubi jalar rebus (18,3 mg/100g) (Rosmalina \& Permaesih, 1997). Pengeringan buah di matahari dan caradehidrasi lain menyebabkan kehilangan sebagian darivitamin A (Azrimaidaliza, 2007). Vitamin A banyak terdapat pada tumbuhan berupa Beta-karoten dengan salah satu cirinya yaitu berwarna kuning sampai orange. Penelitian Kemal dan Karim (2013) mengenai analisis kandungan $\beta$-karoten dan vitamin $\mathrm{c}$ dari berbagai varietas ubi jalar (Ipomoea Batatas), didapatkan bahwa kandungan Beta-karoten ubi jalar kuning $(0,2503 \mathrm{mg} / 100 \mathrm{~g})$ dan orange $(0,8001$ $\mathrm{mg} / 100 \mathrm{~g}$ ) lebih tinggi dibandingkan ubi jalar ungu $(0,1244 \mathrm{mg} / 100 \mathrm{~g})$. Hal tersebut menunjukkan bahwa warna buah juga mempengaruhi banyak atau sedikitnya kandungan vitamin A yang dimiliki.

Kedua, vitamin C. Kandungan vitamin $\mathrm{C}$ yang paling banyak terdapat pada kulit jantung pisang dan kulit buah senduduk yaitu sebesar 263,33 mg dan 111,33 mg. Pada kulit jengkol memiliki sedikit kandungan vitamin $\mathrm{C}$ yaitu $<0,70$. Kandungan vitamin C yang dimiliki oleh jantung pisang

Tabel 1

Rataan Kandungan Vitamin Sampel

\begin{tabular}{lllll}
\hline No & \multicolumn{1}{c}{ Nama Bahan } & Vit A (IU/100g) & Vit C (mg/kg) & Vit E (mg/100g) \\
\hline 1 & Kulit Senduduk & $<0,50 \pm 0,00$ & $111,33 \pm 0,58$ & $0,91 \pm 0,01$ \\
2 & Kulit Jantung Pisang & $<0,50 \pm 0,00$ & $263,33 \pm 1,15$ & $0,92 \pm 0,00$ \\
3 & Kulit Jengkol & $<0,50 \pm 0,00$ & $<0,70 \pm 0,00$ & $0,92 \pm 0,00$ \\
\hline
\end{tabular}


dan buah senduduk ternyata lebih tinggi dibandingkan dengan buah jeruk, kiwi, dan jambu biji yang merupakan sumber vitamin C. Kadar vitamin C pada buah Jambu biji merah (Psidium guajava L.) sebesar 0,429 $\mathrm{mg} /$ gram atau $42,9 \mathrm{mg} / 100$ gram (penelitian (Padang \& Maliku, 2019). Veratamala (2017) menemukan bahwa buah jambu biji memiliki kandungan vitamin C sebesar 200 $\mathrm{mg} / 100 \mathrm{~g}$, kiwi $84 \mathrm{mg} / 100 \mathrm{~g}$, dan jeruk 59$83 \mathrm{mg} / 100 \mathrm{~g}$. Kandungan vitamin C pada buah jeruk 58.30mg/100g (Najwa \& Azlan, 2017). Tingginya kandungan vitamin $C$ yang dimiliki oleh jantung pisang dan buah senduduk sehingga bisa dijadikan sumber antioksidan yang baik, sebab vitamin $\mathrm{C}$ merupakan salah satu sumber antioksidan. Vitamin $\mathrm{C}$ adalah salah satu zat gizi yang berperan sebagai antioksidan efektif atau mengatasi radikal bebas yang dapat merusak sel atau jaringan termasuk melindungi lensa dari kerusakan oksidatif yang ditimbulkan oleh radiasi Wardani (2012).

Ketiga, vitamin E. Rata-rata kandungan vitamin E yang dimiliki oleh keempat sampel hampir sama. Kulit jantung pisang dan kulit jengkol memiliki kandungan vitamin $E$ sebesar 0,92 mg/100g. Kulit buah senduduk sebesar 0,91 mg/100g. Kandungan vitamin $\mathrm{E}$ jenis tumbuhan tersebut tergolong rendah dibandingkan dengan kandungan vitamin $\mathrm{E}$ pada minyak kecambah dan bunga matahari (Lamid, 2012). Kandungan vitamin E minyak kecambah (177,97 IU/100 mg) dan minyak bunga matahari (72,56 IU/100 mg). Tocopherol (vitamin E) alami terkandung pada minyak nabati misalnya minyak kedelai, minyak kecambahn biji kapas, minyak kecambah gandum, dan minyak kecambah biji-bijian yang lain (Pamungkas, 2013).

Tabel 2 menunjukkan bahwa kulit buah senduduk memiliki kandungan antosianin yang tinggi (684.008mg/100g). Tingginya kandungan antosianin pada buah senduduk membuktikan bahwa buah senduduk merupakan salah satu sumber antioksidan alami. Banyaknya kandungan antosianin yang ada pada buah senduduk salah satunya disebabkan oleh faktor zat warna yang dimiliki oleh buah senduduk yaitu memiliki warna ungu pekat. Dengan adanya warna alami yang pekat pada buah senduduk sehingga banyak penelitian yang meneliti tentang ekstrak pigmen

Tabel 2

\begin{tabular}{cll}
\multicolumn{3}{c}{ Hasil Analisis Kandungan Antosianin Sampel } \\
\hline No & \multicolumn{1}{c}{ Nama Bahan } & Antosianin $(\mathrm{mg} / 100 \mathrm{~g})$ \\
\hline 1 & Kulit Senduduk & 684.008 \\
2 & Kulit Jantung Pisang & 174.289 \\
3 & Kulit Jengkol & 166.718 \\
\hline
\end{tabular}


antosianin buah senduduk untuk dijadikan sebagai pewarna alami pada olahan makanan (Purba, 2018; Sulasono, 2014).

Dilihat dari semua sampel bisa dijadikan sebagai antioksidan alami tinggal tingkatan kandungannya ada yang banyak dan tidak. Yang berpotensi sebagai antioksidan alami dilihat dari analisis kandungan vitamin A, C, E, dan kandungan antosianin; maka didapatkan bahwa buah senduduk dan jantung pisang bisa dijadikan sebagai antioksidan alami yang baik.

\section{SIMPULAN}

Aktivitas antioksidan alami yang paling tinggi menurut analisis kandungan vitamin $\mathrm{A}, \mathrm{C}, \mathrm{E}$ dan antosianin dari ketiga limbah tanaman (buah senduduk, jantung pisang, kulit jengkol), terdapat pada kulit buah senduduk dan kulit jantung pisang yaitu kandungan vitamin $\mathrm{C}(111,33 \mathrm{mg} /$ $\mathrm{kg}$ dan $263,33 \mathrm{mg} / \mathrm{kg}$ ) dan kandungan antosianin $(684,008 \mathrm{mg} / 100 \mathrm{~g}$ dan 174,289 $\mathrm{mg} / 100 \mathrm{~g})$.

\section{DAFTAR PUSTAKA}

Azrimaidaliza, A. (2007). Vitamin A, imunitas dan kaitannya dengan penyakit infeksi. Jurnal Kesehatan Masyarakat Andalas, 1(2), 90-96.

Kemal, N., \& Karim, A. (2013). Indonesia Chimica Acta Analisis Kandungan B -Karoten Dan Vitamin C Dari Berbagai Varietas Ubi Jalar ( Ipomoea batatas). Indonesia Chimica Acta, 1-8.

Kumaran, A., \& Karunakaran, R. (2006). Antioxidant and free radical scavenging activity of an aqueous extract of Coleus aromaticus. Food Chemistry, 97(1), 109-114. https://doi.org/10.1016/j. foodchem.2005.03.032.

Lamid, A. (2012). Vitamin E Sebagai Antioksidan. Media of Health Research and Development, 5. https://doi. org/10.22435/mpk.v5i01Mar.701.

Lung, J. K. S., \& Destiani, D. P. (2017). Uji aktivitas antioksidan vitamin $\mathrm{A}, \mathrm{C}, \mathrm{E}$ dengan metode DPPH. Farmaka, 15(1), 53-62.

Najwa, R. F. \& Azlan, A. (2017). Comparison of vitamin $\mathrm{C}$ content in citrus fruits by titration and high performance liquid chromatography (HPLC) methods. International Food Research Journal, 24(2), 726-733.

Okezone. (2018). WHO prediksi penderita kanker di Indonesia naik 7 kali lipat pada 2030. Diunduh dari https:// lifestyle.okezone.com/.

Padang, S. A., \& Maliku, R. M. (2019). Penetapan kadar vitamin C pada buah jambu biji merah (Psidium guajava L.) dengan metode titrasi Na-2,6 Dichlorophenol Indophenol (DCIP). Media Farmasi, 13(2), 30-35. https:// doi.org/10.32382/mf.v13i2.879.

Pamungkas, W. (2013). Aplikasi vitamin E dalam pakan: Kebutuhan dan peranan untuk meningkatkan reproduksi, sistem imun, dan kualitas daging pada ikan. Media Akuakultur, 8(2), 145. https://doi. org/10.15578/ma.8.2.2013.145-150.

Purba, S. R. (2018). Pemanfaatan zat pewarna alami dari buah senduduk bulu (clidemia hirta) sebagai pengganti zat pewarna sintetik pada pembuatan es krim serta uji daya terimanya (Skripsi tidak diterbitkan). Fakultas Kesehatan Masyarakat Unviersitas Sumatera Utara, Medan.

Rosmalina, Y., \& Permaesih, D. (1997). Hasil analisis vitamin a dan $\beta$-karoten bahan makanan sumber vitamin A dan karoten dengan metode HPLC. Penelitian Gizi dan Makanan (The Journal of Nutrition and Food Research), 20. 
Sulasono, J. T., Martono, A., Ratnawati, D. (2014). Pemanfaatan ekstrak buah senduduk ungu (Melastoma malabathricum L.) sebagai pewarna dan pengawet pada tahu (Tesis tidak diterbitkan). Universitas Bengkulu.

Veratamala, A. (2017). 6 buah yang paling tinggi vitamin C, selain jeruk. Hellosehat. com. https://hellosehat.com/.
Wardani, L. A. (2012). Validasi metode analisis dan penentuan kadar vitamin C pada minuman buah kemasan dengan spektrofotometri UV-visible (Skripsi tidak diterbitkan). Fakultas Matematika dan Ilmu Pengetahuan Alam Universitas Indonesia, Depok. 